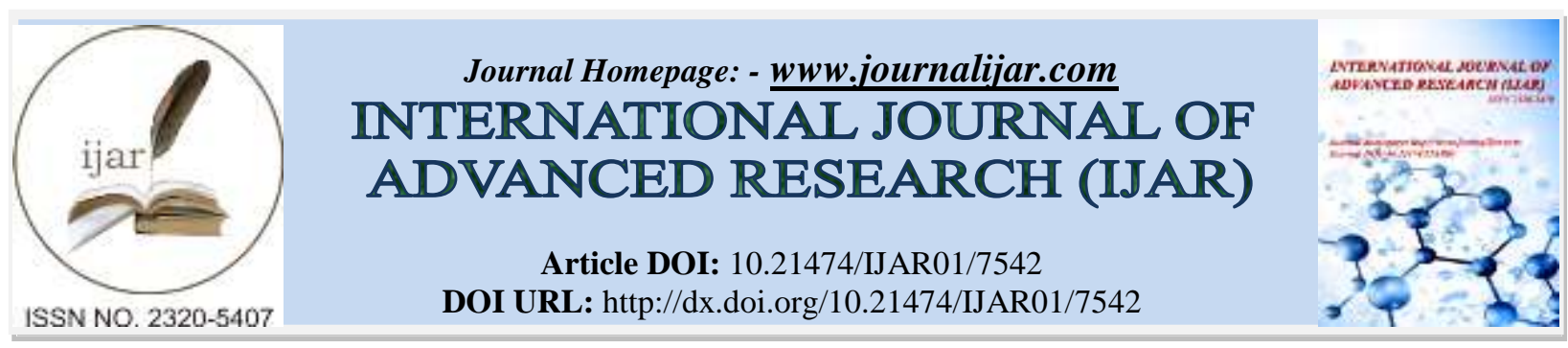

RESEARCH ARTICLE

\title{
THE EFFECT OF COMPETENCE, COMMITMENT, AND REGULATION ON THE ACCOUNTABILITY OF VILLAGE FINANCIAL MANAGEMENT WITH MODERATED SPIRITUALITY.
}

\author{
Wana Mariska ${ }^{1}$, Ratna Ayu Damayanti ${ }^{2}$ and Yohanis Rura ${ }^{2}$. \\ 1. Magister of Accounting, Hasanuddin University, Indonesia. \\ 2. Economics and Business Faculty, Hasanuddin University, Indonesia.
}

\section{Manuscript Info}

Manuscript History

Received: 25 July 2018

Final Accepted: 01 August 2018

Published: 31 August 2018

Key words:

Competence, commitment, regulation, spirituality, and accountability of village financial management.

\section{Abstract}

The decentralization of the village to demand that the financial management of the village made accountable. This study aims to determine the effect of competence, commitment, and regulation on the accountability of village financial management with moderated spirituality. The population in this study were 238 village heads in Bone regency. Sample selection method used is convenience sampling, so that obtained sample of 180 village heads. The data obtained were analyzed using Moderated Regression Analysis (MRA). The results of this study showed that (1) competence has a positive effect on the accountability of village financial management, (2) commitment has a positive effect on the accountability of village financial management, (3) regulation has a positive effect on the accountability of village financial management, (4) spirituality can strengthen the effect of competence on accountability of village financial management, dan (5) spirituality can strengthen the effect of commitment on accountability of village financial management.

Copy Right, IJAR, 2018,. All rights reserved.

\section{Introduction:-}

January 15, 2014 has been the beginning for the sustainability of the development of decentralization in Indonesia. This can be seen with the enactment of the Village Law. The ratification of the Village Law is evidence that decentralization has not only reached the local government, but has evolved to the village government.

The implementation of village government should be able to put forward the principles that can lead to the creation of good governance. The government is required to be able to manage the region well and take advantage of all the resources that are owned for the prosperity of the community. One of the principles that governments must apply in managing village finances is accountability (Mardiasmo, 2009).

Some research in the field suggest that the level of government accountability in the village is still very low. The irregularities in village financial management conducted by the village government apparatus are becoming the hot news that has been lately discussed lately. Even the news on social media often presents the news. One social media reports said that of the nearly 75 thousand villages in Indonesia, which oversees the village and about 200 are caught in legal cases for misappropriation of funds village (Aziz, 2017). 
This study discusses the accountability of village financial management in Bone District. Bone District is the district that receives the largest village funds from 21 districts in South Sulawesi. Village funds should be managed by the village head well in the interests of the community. However, the national phenomenon associated with the irregularities of village financial management also can not be denied occurred in Bone District. In 2017, there was a case of village fund corruption involving the Polewali Village Chief, Kajuara Sub-District causing a state loss of 160 million (Mattola, 2017). Then in 2018, Village Head Maddanrengpulu, Sub-District Patimpeng also involved corruption case of village funds that resulted in state losses amounted to 463 million (Ibrahim, 2018).

This indicates that the village head did not perform his duties as stipulated in the Village Law. Whereas, in Article 26 paragraph (4) of Law No. 6 of 2014 states that the village head is obliged to implement the principle of village governance accountable, transparent, professional, effective, efficient, and free from corruption, collusion and nepotism. This phenomenon is also contradictory to the stewardship theory which becomes the reference in carrying out the accountability of village financial management. As the stewardship theory assumes that management is not motivated by individual goals but is intended for the benefit of the organization. In a sense, the village head should prioritize the interests of the village community rather than his own interests.

The findings of the Indonesia Action-Coruption Forum (IACF) mention the potential misuse of village funds due to the competence of the village apparatus. Makalang et al. (2017) states that the competence of the apparatus is the main obstacle in carrying out accountability. This is supported by previous studies such as Nofianti and Novie (2014), Mada et al. (2017) and Indriasih and Poppy (2014) stating that competence affects performance accountability. This result, however, contradicts the findings of Widyatama et al. (2017) found that accountability was not influenced by the level of competence of the village head.

In addition to competence, commitment also influences the accountability of village financial management. Cavoukian et al. (2010) states that organizational commitment is required in the implementation of accountability. Individuals with organizational commitment tend to develop greater efforts on the job for the success of their organization, including in terms of accountable financial management. this is supported by the findings of Kitta et al. (2014) and Mada et al. (2017) that there is an influence between commitment and accountability. However, the results of this study differ from the findings Aimbu et al. (2017) which shows commitment has no effect on financial management accountability.

This study differs from previous studies because of the variables of regulation and spirituality that were added in examining its effect on accountability in village financial management. The relationship of these two variables to the accountability of village financial management can be studied by attribution theory. As assumed in attribution theory that a person's behavior is due to internal or external attributes (Malle, 2011).

One of the external attributes that influences a person in managing is regulation. Regulation governing the behavior of a person to perform an action based on those rules. Rofika and Ardianto (2014) argued that the implementation of accountability should be supported by adequate regulations as a reference in implementing financial management.

The internal attributes that can affect a person's behavior that is spirituality. Spirituality is the value, attitude, and behavior associated with morality. McCuddy and Pirie (2007) assert that spirituality does not emphasize the importance of the material, but more attention to the use and management of resources. The use and management of resources undertaken by the steward must be accountable for the achievement of an accountable government. Based on the phenomenon and findings of previous research, this study would like to examine the influence of competence, commitment, and regulation on the accountability of village financial management with moderated spirituality.

\section{Literature Review And Hypotheses:-}

\section{a. Stewardship Theory}

Stewardship theory is part of agency theory that describes a condition in which management is not motivated by individual goals, but is intended for the benefit of the organization (Donalson and Davis, 1991). The stewardship theory assumes a relationship that describes the maximization of the principal and management functions (stewards). In the development of stewardship theory can be applied to public sector organizations to meet the information needs for the relationship between management (stewards) and principal. Increasing the demand for 
accountability in public sector organizations, the management functions become increasingly difficult to implement by the principal themselves. This resulted in the need for a separation between the ownership function and the management function.

The concept of stewardship theory is based on the principle of trust to the steward. Steward is seen as a good steward who performs the task responsibly. Good steward can be realized if the steward has the competence and commitment. Competence is needed stewards to be able to carry out the duties and responsibilities mandated to him. While commitment is required for stewards can act cooperatively for the achievement of organizational goals. Therefore, stewardship theory in this research is used to explain competence and commitment variable in relation to accountability of village fund management.

\section{b. Attribution Theory}

Fritz Heider introduced attribution theory in 1958. This theory assumes about how someone explain the cause of the behavior of others or himself. attribution theory states that when individuals observing someone's behavior, they try to determine whether it is caused internally or externally (Malle, 2011). Malle (2011) suggests that there are internal attributions (personal attributes) and external attributes (environmental attributes) that together affect human behavior. Internally induced behavior is a behavior that is believed to be under the personal control of the individual itself or from internal factors. While the behavior caused externally is behavior that is influenced from outside or from environmental factors.

Attribution theory in this research is used to explain regulation and spirituality as attribution that influence steward to manage village fund management accountably. Regulation is an external attribute that can influence the steward to act in accordance with the provisions set forth in the regulation. While spirituality is an internal attribute of values, attitudes, and behaviors that are intrinsically motivating oneself and others so as to have a sense of spiritual survival (McCuddy and Pirie, 2007).

\section{c. Hypothesis}

The stewardship theory assumes that no state or situation of management is motivated for individual purposes but rather focuses on organizational interests (Donaldson and Davis, 1991). The existence of the limitations possessed by the community as the owner of the resources (principal), resulted in giving the trust of resource management to the village head (steward). Contract relationship between principal and steward is based on trust and collective in accordance with organizational goals. Therefore, the existence of the village head as a trustworthy steward can accommodate the aspirations of the community and provide good service, it is necessary to make accountability of village financial management mandated to him. In the sense that the village head must perform accountable financial management.

Competence is the basic capital of a person or organization in realizing the achievement of organizational goals. Public sector organizations strongly emphasize the ability of good service to the community, so public sector organizations have a good performance and accountable in the community. Understanding of village financial management becomes an important and fundamental aspect that must be owned by the village apparatus, especially the village head.

The concept of stewardship theory is based on the principle of trust to the party given authority, namely steward. Steward is seen as a good steward who performs the task responsibly. Good steward can be realized if the steward has the competence. This is because the organization will speak the right man on the right place. The statement indicates that the organization must be filled by people who have competence according to the position of which the responsibility.

Several previous studies have examined the relationship of competence and accountability of financial management, such as Nofianti and Novie (2014) and Indriasih and Poppy (2014). The results of research conducted by Nofianti and Novie (2014) showed that the competence of local government apparatus has a positive influence in the implementation of performance accountability. Similarly, Indiasih and Poppy (2014) find that adequate competence of local government apparatus in terms of quantity and quality of content will increase the value of information in the accountability of local government financial reporting. This result, however, contradicts the findings of Widyatama et al. (2017) and Rofika and Ardianto (2014) stating that competence has no effect on accountability. Therefore, the developed hypothesis is: 
H1. Competence has a positive effect on the accountability of village financial management.

Commitment is the key to success that must be obeyed by all employees in achieving organizational goals. As stewardship assumes that stewards perceive mutual interests and behave in accordance with principal interests is a rational consideration, since stewards are more concerned with efforts to achieve organizational goals (Raharjo, 2007). The model of man on stewardship theory assumes that the steward will replace and divert the self serving to cooperate. Therefore, in the context of this research, the village head as a steward must have a commitment to the organization for organizational objectives can be achieved, one of which is by managing accountable village funds.

Several previous studies have examined the relationship of organizational commitment and financial management accountability, such as Kitta et al. (2014) and Mada et al. (2017) whose research results show that organizational commitment has a positive effect on financial management accountability. However, the results of this study differ from the findings Aimbu et al. (2017) indicating that organizational commitment has no effect on financial management accountability. Therefore, the developed hypothesis is:

\section{H2. Commitment positively affects the accountability of village financial management.}

The attribution theory introduced by Fritz Heider in 1958 describes the causes of the behavior of others or of themselves. As the attribution theory assumes that one's actions or behavior are due to internal attributes or external attributes. Regulation or legislation is one of the external attributes that governs or becomes the reference of a person in acting. Therefore, in the context of this study regulation is used as an external attribute in influencing accountable financial management.

The regulations that become the reference in the management of village finances are regulated in Peraturan Menteri Dalam Negeri Nomor 113 Tahun 2014. The management of village finances must be accountable in accordance with the provisions stipulated in the regulation. Peraturan Menteri Dalam Negeri Nomor 113 Tahun 2014 mandates that village finances be managed with the principles of transparent, accountable, participatory, and carried out with the order and budget discipline. Goddard (2005) argues that the emergence of regulations in a country is often associated with changes in privatization policies that lead to the emphasis of transparency and accountability. This is also confirmed by Rofika and Ardianto (2014) who argued that the implementation of accountability must be supported by adequate regulations as a reference in implementing financial management. Based on this description then the hypothesis that can be developed is:

\section{H3. Regulation has a positive effect on the accountability of village financial management.}

Spirituality as an internal attribute is related to intrinsic motivation. Intrinsic motivation is a feeling condition with an interest in doing an activity driven by something fundamentally within oneself, such as beliefs, norms, and ethical values (Fry et al., 2010). Individuals with intrinsic motivation are actively involved in the completion of tasks in accordance with their powers and responsibilities. To achieve this, intrinsic motivation is believed to be the result of the individual's basic needs to improve competence.

Leaders or stewards with high spirituality are likely to engage in congruent behavior with the values, beliefs, and positive motivations that the leader possesses (Fry et al., 2010). The steward belief that they have the ability to accomplish their tasks and responsibilities is well embodied in positive affection in the form of competence as a standard of behavior in financial management. In the sense that, stewards with high spiritual values will motivate themselves to have competencies that match their duties and responsibilities in order to perform accountable financial management. Based on this description then the hypothesis that can be developed is:

\section{H4. Spirituality can strengthen the effect of competence to the accountability of the financial management of the village.}

McCuddy and Pirie (2007) argue that spirituality is an internal attribute of values, attitudes, and behaviors that intrinsically motivate oneself and others so as to have a sense of spiritual survival. Spiritual leadership has the need to create open communication and begin conversations with spiritual ideas related to the delivery of vision, hope, and altruistic love that will make it feel compelled and part of the organization (Fairholm and Taylor, 2015).

In addition, stewards who have high spiritual values will devote maximum effort and cooperative action, so that commitment to the organization also increases (Fry et al., 2010). In other words, spirituality can encourage a person to have a commitment to the organization. This makes the steward feel involved in the organization and affectionally has an emotional bond with the organization, so that steward can carry out the duties and 
responsibilities in accordance with the mandate of the principal. In the sense that it can perform accountable financial management Based on this description then the hypothesis that can be developed is:

H5. Spirituality can strengthen the influence of commitment to the accountability of village finance management.

\section{Methodology:-}

This research uses quantitative approach with correlation method. The population in this study were 238 village heads in Bone regency. Sample selection method used is convenience sampling, so that obtained sample of 180 village heads. The data collection in this research was conducted by using survey method, by distributing research questionnaires to the respondents. The data obtained were analyzed using Moderated Regression Analysis (MRA).

The variables in this study have each measurement, namely:

1. Accountability of village financial management is the decisive principle that any activity including planning, implementation, administration, reporting, and accountability of village finances should be accountable to the village community in accordance with the provisions of legislation. Indicators used to measure the accountability of village financial management were developed from the Aimbu et al (2017) questionnaire consisting of legal and honesty accountability, managerial accountability, program accountability, accountability and financial accountability.

2. Widyatama et al. (2017) defines competence as a fundamental characteristic of a person who directly influences what is done. The indicators used to measure competencies were developed from the Aimbu et al (2017) questionnaire consisting of knowledge, skills and behavior.

3. Mowday et al. (1982) describes organizational commitment as a sense of identification (trust in organizational values), involvement (willingness to do the best possible for the benefit of the organization) and loyalty (the desire to remain a member of the organization concerned) declared by an employee to the organization. Indicators used to measure commitment were developed from Allen and Meyer (1990) questionnaire consisting of affective commitment, ongoing commitment, and normative commitment.

4. Goddard (2005) defines the regulation as a standard or a rule in accordance with the policies established by the government for public activities to be carried out by the community. The regulation referred to in this study is the related regulation on the management of village finances as regulated in the Peraturan Menteri Dalam Negeri Nomor 113 Tahun 2014. Indicators used to measure the regulation developed from Peraturan Menteri Dalam Negeri Nomor 113 Tahun 2014 which consists of the principle of village financial management, power village financial management, and village financial management.

5. Ahmadi et al. (2014) states that spirituality is at the core of the individual's identity and helps develop inner values and morality. This study focuses on spirituality in leadership or commonly termed spiritual leadership. The leadership perspective shows that leaders or leaders have spirituality and have a transformational effect on organization, form, structure, process, behavior, and attitude. The indicators used to measure spiritual leadership were developed from the Fry et al (2010) questionnaire consisting of hope/ confidence, vision, and altruistic love.

\section{Results and Discussion:-}

\section{Competence has a positive effect on the accountability of village financial management}

The results of regression analysis for the relationship between competence and accountability of village financial management have a probability value of $0.001(<0.05)$. This value indicates that the relationship between competency and accountability of village financial management has a significant effect. In addition, the coefficient value for the competency variable is 0.189 which indicates that the direction of the relationship between competency and accountability of village financial management is positive. This means that the higher the competence possessed by the village head will lead to higher levels of accountability in village financial management. Thus, hypothesis 1 which states that "competency has a positive influence on the accountability of village financial management" is accepted.

The results of this study are in accordance with the stewardship theory, which emphasizes stewards/executives as managers who are motivated to do their best to the main interests of the organization. Stewardship theory emphasizes that stewards/executives as managers have a role in achieving organizational goals. Stewards/executives as managers can be translated into the scope of village financial management, in this case the village head is a steward/executive who is responsible for managing village finances. Therefore, the existence of the village head as a steward who is believed to be able to accommodate the aspirations of the community and provide good service, 
needs to make the accountability of the village financial management mandated to him. In the sense that village financial management has been accountably carried out by the village head.

The concept of stewardship theory is also based on the principle of trust in the party given authority, namely the steward. Stewards are seen as good stewards who carry out their duties responsibly (Donalson and Davis, 1991). Good stewards can be realized if the steward has competence. This is because the organization will speak the right man on the right place. The statement indicates that the organization must be filled by people who have competence in accordance with the position of their responsibility.

The results of this study are in line with several previous studies such as Nofianti and Novie (2014) and Indriasih and Poppy (2014). The results of research conducted by Nofianti and Novie (2014) show that the competence of local government officials has a positive effect on the implementation of performance accountability. Likewise, the results of research by Indiasih and Poppy (2014) found that adequate competency of local government apparatuses in terms of quantity and quality of content would increase the value of information in accountability of local government financial reporting.

\section{a. Commitment has a positive effect on the accountability of village financial management}

The results of regression analysis for the relationship between commitment and accountability of village financial management have a probability value of $0.010(<0.05)$. This value indicates that the relationship between commitment and accountability of village financial management has a significant effect. In addition, the coefficient value for the commitment variable is 0.148 which indicates that the direction of the relationship between commitment and accountability of village financial management is positive. This means that the higher the commitment of the village head will lead to higher levels of accountability for village financial management. Thus, hypothesis 2 states that "commitment has a positive influence on the accountability of village financial management" is accepted.

The results of this study are in line with the stewardship theory which assumes that the steward feels that mutual interests and behave in accordance with the principal's interests are rational considerations because the stewards are more concerned with efforts to achieve organizational goals (Raharjo, 2007). The model of man in stewardship theory assumes that the steward will replace and divert self-serving to cooperative action (Donalson and Davis, 1991). Therefore, village heads who have a commitment to the organization mobilize their abilities to achieve organizational goals, one of which is by carrying out accountable village fund management.

The results of the study are supported by several previous studies that have examined the relationship of organizational commitment and financial management accountability, such as Kitta et al. (2014) and Mada et al. (2017) whose research results show that organizational commitment has a positive effect on financial management accountability. Based on this, it can be concluded that commitment has a positive effect on the accountability of village financial management. This means that the higher the commitment of the village head, the greater the accountability of village financial management.

\section{b. Regulation has a positive effect on the accountability of village financial management}

The results of regression analysis for the relationship between regulation and accountability of village financial management have a probability value of $0,000(<0,05)$. This value indicates that the relationship between regulation and accountability of village financial management has a significant effect. In addition, the coefficient value for the regulation variable is 0.374 which indicates that the direction of the relationship between regulation and accountability of village financial management is positive. This means that the clearer regulations related to village financial management will result in higher levels of accountability for village financial management. Thus, hypothesis 3 states that "regulation has a positive effect on the accountability of village financial management" is accepted.

The results of this study are in line with attribution theory which explains the causes of other people's behavior or themselves. As assumed attribution theory that a person's actions or behavior is caused by internal attributes or external attributes. Regulation or statutory regulation is one of the external attributes that govern or become a reference for someone in acting. Therefore, in the context of this study regulation as an external attribute influences financial management accountability. 
The results of this study are supported by previous research, including Goddard (2005) which states that the emergence of regulation in a country is often associated with changes in privatization policies which lead to an emphasis on transparency and accountability. This was also confirmed by Rofika and Ardianto (2014) who stated that the implementation of accountability must be supported by adequate regulations as a reference in carrying out financial management.

\section{c. Spirituality strengthens the influence of competencies on the accountability of village financial management}

The results of regression analysis for the interaction between competence and spirituality have a probability value of $0.039(<0.05)$. This value indicates that spirituality can moderate the influence of competencies on the accountability of village financial management. In addition, the $\mathrm{R}$ square value after the competency variable interacts with the spirituality variable has increased by 0.014 or $1.4 \%$, from 0.586 or $58.6 \%$ to 0.600 or $60 \%$. This value indicates that the existence of a spirituality variable can strengthen the influence of competencies on the accountability of village financial management. Thus, hypothesis 5 which states that "spirituality can strengthen the influence of competencies on village financial management accountability" is accepted.

The results of this study are in line with attribution theory which assumes that the cause of one's behavior is due to internal or external attributes. Spirituality is an internal attribute in the form of values, attitudes, and behaviors related to morality. Spirituality as an internal attribute is closely related to intrinsic motivation. Intrinsic motivation is a condition of feeling with an interest in doing an activity by being driven by something that is fundamentally found in yourself, such as beliefs, norms, and ethical values (Fry et al., 2010). Individuals who have intrinsic motivation are actively involved in completing tasks according to their authority and responsibilities. To realize this, intrinsic motivation is believed to be the result of the basic needs of individuals to improve competence.

\section{d. Spirituality strengthens the influence of commitment on the accountability of village financial management}

The results of regression analysis for the interaction between commitment and spirituality have a probability value of $0.000(<0.05)$. This value indicates that spirituality can moderate the influence of commitment to the accountability of village financial management. In addition, the $\mathrm{R}$ square value after the commitment variable interacts with the spirituality variable has increased by 0.037 or $3.7 \%$, from 0.586 or $58.6 \%$ to 0.623 or $62.3 \%$. This value indicates that the existence of a spirituality variable can strengthen the influence of commitment to the accountability of village financial management. Thus, hypothesis 6 which states that "spirituality can strengthen the influence of commitment to village financial management accountability" is accepted.

The results of this study are in line with attribution theory which assumes that the cause of one's behavior is due to internal or external attributes. Spirituality as an internal attribute is closely related to intrinsic motivation. McCuddy and Pirie (2007) suggested that spirituality is an internal attribute in the form of values, attitudes, and behaviors that intrinsically motivate themselves and others so that they have a feeling of spiritual survival. Spiritual leadership has a need to create open communication and start talking with spiritual ideas related to the delivery of altruistic vision, hope and love that will make him feel called and become part of the organization (Fairholm and Taylor, 2015).

In addition, stewards who have high spirituality values will devote effort maximally and act cooperatively, so that commitment to the organization will increase (Fry et al., 2010). In other words, spirituality can encourage someone to have a commitment to the organization. This makes the steward feel involved in the organization and has an emotional bond with the organization, so that the steward can carry out the duties and responsibilities in accordance with the mandate of the principal. In the sense that it can carry out financial management accountably.

\section{Conclusions and Recommendations:-}

Based on the findings of the study, it can be concluded that competence, commitment and regulation have a positive effect on the accountability of village financial management. While spirituality can strengthen the influence of competence and commitment to the accountability of village financial management. The results of this study can have implications for the government to consider the factors in this study considered to have an effect on the accountability of village financial management.

The independent variables used in this study are still limited. Not all issues that are a topic trend related to the accountability of village financial management are included in the study. The instrument used in this study is the 
result of modification from previous research and the results of the research design based on important indicators in the Minister of Home Affairs Regulation No. 113 of 2014 concerning village financial management. Even though the researcher anticipates by testing the validity and reliability, this still allows the respondent to make an overestimate or close-down (closing the real thing) by answering it as if. Therefore, the researcher can then add other variables that are feasible to be used to determine the accountability of village financial management that have not been included in this study and can improve the questionnaire used in this study.

\section{References:-}

1. Aimbu, Lesli., David, Saerang., dan Hendrik, Gamaliel. (2017). Analisis Determinan Akuntabilitas Pengelolaan Keuangan Daerah. Tesis. Program Pascasarjana Universitas Sam Ratulangi.

2. Aziz, Abdul. (2017). Pengelolaan Dana Desa: Kemenkeu Sebut 200 Desa Terkena OTT. Diunduh 20 Desember 2017. https://tirto.id/pengelolaan-dana-desa-kemenkeu-sebut-200-desa-terkena-ott-cB1V .

3. Cavoukian, Ann., Taylor, Scott., dan Abrams, Martia. (2010). Privacy by Design: Essential for Organizational Accountability and Strong Business Practices. Vol.3.

4. Donaldson, L. dan Davis, J.H. (1991). Stewardship Theory or Agency Theory: CEO Governance and Stakeholder Returns. Australian Journal of Management, Vol.16, No.1.

5. Fairholm, M.R. dan Taylor W, Gronau. (2015). Spiritual Leadership in Work of Public Administrators. Journal of Management, Spirituality and Religion, Vol.12.Fry, Louis W., Laura L, Matherly., dan J-Robert, Ouimet. (2010). The Spirituality Leadership Balanced Scorecard Business Model. Journal of Management, Spirituality, and Religion, Vol.7.

6. Ghozali, Imam. (2013). Aplikasi Analisis Multivariate dengan Program IBM SPSS 21. Semarang: Universitas Diponegoro.

7. Goddard, Andrew. (2005). Reform as Regulation-Accounting, Governance and Accountability in UK Local Government. Journal of Accounting and Organizational Change,Vol.1.

8. Hewett, Rebecca., Amanda Shantz., Julia Mundy., dan Kerstin Alfes. (2017). Attribution Theories in Human Resource Management Research: A Review and Research Agenda. International Journal of Human Resource Management.

9. Ibrahim, Supriadi. (2018). Gunakan Dana Desa Tuk Kuliah S2, Kades di Bone jadi Tersangka. Diunduh, 2 Februari 2018. https://makassar.sindonews.com/read/4573/4/gunakan-dana-desa-tuk-kuliah-s2-kades-di-bone-jadi-tersangka1517306493

10. Indriasih, Dewi dan Poppy, Sofia K. (2014). The Effect of Government Apparatus Competence and The Effectiveness of Government Internal Control Toward The Quality of Financial Reporting and Its Impact on The Performance Accountability in Local Government. South East Asia Journal of Contemporary Business, Economic and Law, Vol. 5, Issue 1.

11. Kitta, Syafruddin., Rakhmat., Heri, Tahir., dan Andi, Munarfah. (2014). Analysis of Determinant Factors in Regional Financial Management Accountability in Local Government at Maros Regency. International Journal of Academic Research, Vol.6, No.3.

12. Mada, Syarifudin., Lintje, Kalangi., dan Hendrik, Gamaliel. (2017). Pengaruh Kompetensi Aparat Pengelola Dana Desa, Komitmen Organisasi, dan Partisipasi Masyarakat Terhadap Akuntabilitas Pengelolaan Dana Desa di Kabupaten Gorontalo. Tesis. Program Pascasarjana Universitas Sam Ratulangi.

13. Makalang, A.J., Grace, B.N., dan Herman, K. (2017). Akuntabilitas Pengelolaan Dana Desa di Kecamatan Kotamobagu Selatan Kota Kotamobagu. Tesis. Program Pascasarjana Universitas Sam Ratulangi.

14. Malle, Bertram F. (2011). Attribution Theories: How People Make Sense of Behavior. Wiley-Blackwell.

15. Mardiasmo. (2009). Akuntansi Sektor Publik. Yogyakarta: Penerbit Andi.

16. Mattola, A.G. (2017). Korupsi ADD, Kades Polewali Bone jadi Tersangka. Diunduh, 20 Desember 2017. http://lintasterkini.com/08/08/2017/korupsi-add-tahun-2015-mantan-kades-polewali-bone-jadi-tersangka.html

17. McCuddy, M. dan Pirie, Wendy L. (2007). Spirituality, Stewardship, and Financial Decision-Making: Toward a Theory of Intermporal Stewardship. Managerial Finance, Vol. 33.

18. Nofianti, L. dan Novie, Susanti S. (2014). Factor Affecting Implementation of Good Government Governance (GGG) and Their Implication Towards Performance Accountability. International Conference on Accounting Studies.

19. Rofika dan Ardianto. (2014). Pengaruh Penerapan Akuntabilitas Keuangan, Pemanfaatan Teknologi Informasi, Kompetensi Aparatur Pemerintah Daerah dan Ketaatan Peraturan Perundangan Terhadap Akuntabilitas Kinerja Instansi Pemerintah. Jurnal Akuntansi, Vol. 2 No.2.

20. Widyatama, Arif., Lola, Novita., dan Diarespati. (2017). Pengaruh Kompetensi dan Sistem Pengendalian Internal Terhadap Akuntabilitas Pemerintah Desa dalam Mengelola Alokasi Dana Desa (ADD). Berkala Akuntansi dan Keuangan Indonesia, Vol.2 no.2. 